\title{
Dansk krigsfangehjælp i Rusland og Sibirien 1917-1920
}

Danmark spillede som neutral stat under verdenskrigen en vigtig international rolle for hjalpearbejde $i$ Rusland, men emnet er overset $i$ dansk historieskrivning. Danmark var fra april 1917 til juni 1918 beskyttelsesmagt for Østrig-Ungarn og varetog krigsfangehjalpen til halvanden million østrig-ungarske krigsfanger, der sad i lejre i Rusland og Sibirien. Det danske gesandtskab i Petersborg (Petrograd) organiserede hjalpearbejde og hjemsendelse afkrigsfanger. Efter Danmarks diplomatiske brud med Sovjetrusland i december 1918 fortsatte arbejdet under Dansk Røde Kors, indtil bolsjevikkerne arresterede og udviste Dansk Røde Kors-medarbejderne i juni 1919. Det danske initiativ fortsatte i Sibirien, men iforaret 1920 blev samtlige danskere evakueret fra Sovjetrusland og Sibirien.

af Bernadette Preben-Hansen, filolog, mag.art.

I 1959 publicerede Erik Scavenius sine erindringer om "Dansk udenrigspolitik under den første verdenskrig". Han var udenrigsminister under begge verdenskrige og statsminister nogle år under besættelsen. Udover at Scavenius' erindringer er velskrevne og politisk fremsynede, er

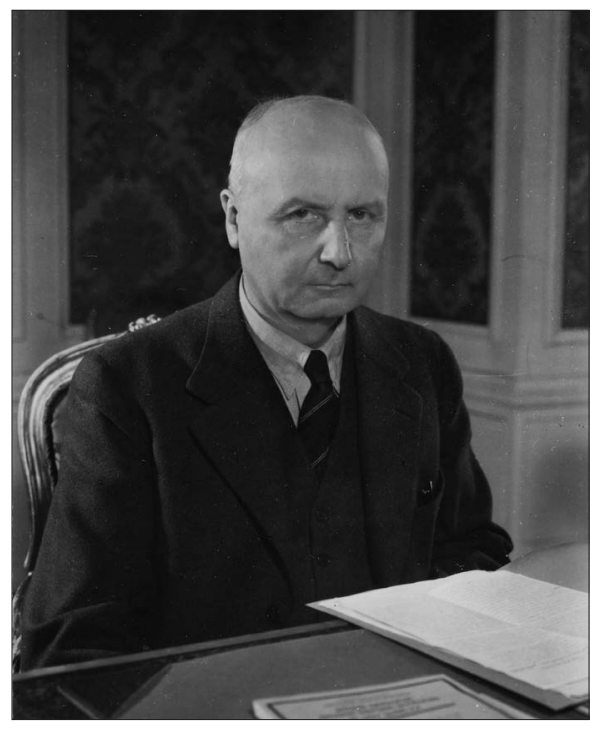

Erik Scavenius (Det Kongelige Bibliotek, Billedsamlingen). det også interessant, hvad Scavenius ikke erindrer. Han skriver nemlig ikke ét ord om Danmarks internationale ansvar som stormagt for humanitært hjælpearbejde under verdenskrigen. Her ses intet om dansk krigsfangehjælp i Rusland og Sibirien i verdenskrigens sidste år 1917-18, under bolsjevikkernes statskup i oktober/november 1917 og under den russiske borgerkrig $i$ 1918-20. Erindringerne behandler, skriver Scavenius, "alene de begivenheder i dansk indenrigspolitik, som har forbindelse med tidens danske udenrigspolitik".

Det er ligeledes bemærkelsesværdigt, at gængse Danmarkshistorier heller ikke nævner emnet, samt at der omtrent ingen moderne publiceret litteratur findes på dansk. Undtagelserne er spredte bemærkninger hos Inge Adriansen, Bent Blüdnikow og Bent Jensen (se: Litteratur). Og der er her et stort emne for studiet af Danmarks neutralitetshistorie under internationale konflikter, ikke mindst da der her er tale om politiske og logistiske operationer af dimensioner. Bare se på Ruslands og Sibiriens geografi - der er ti tusind kilometer fra Kijev til Vladivostok. Men nu til en anden Scavenius: Harald. 


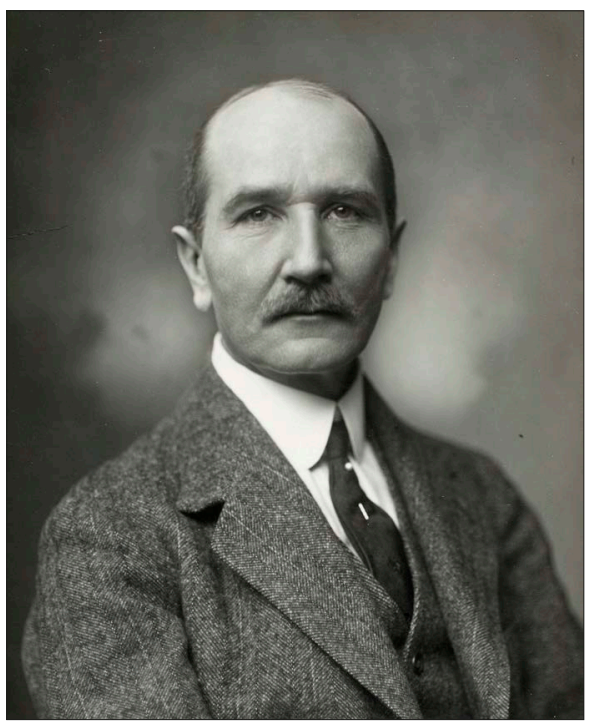

Harald Scavenius (Det Kongelige Bibliotek, Billedsamlingen).

\section{Harald Scavenius}

Harald Scavenius var Danmarks gesandt i Rusland med residens i Petersborg fra 1912 indtil Danmarks diplomatiske brud med Sovjetrusland i december 1918. Han havde $i$ øvrigt overtaget posten fra en anden fætter: Otto Scavenius. Harald var rystet i sin grundvold over 1917-samfundsomvæltningens konsekvenser og borgerkrigen. Han havde en klar fornemmelse af totalitarismen i Lenins politik og anså bolsjevismen for en trussel ikke kun for Rusland, men for hele Europa: "en trussel mod afgørende åndelige værdier i de vestlige samfund" som han udtalte ved Fredskonferencen i Versailles. I december 1918 måtte han aldeles modvilligt forlade Petersborg og rejse til København, hvor han blev sat udenfor nummer af sin fætter Erik, der ville forvise ham som gesandt til Oslo. De to fætre udvekslede diplomatiske breve som henholdsvis gesandt og udenrigsminister, men privatbrevenes tone klinger derimod langt fra af diplomatiet. Harald nægtede at lade sig forvise til Oslo. I januar 1919 rejste Harald i privat regi til Fredskonferencen i Versailles for at agitere for en militær intervention af Rusland med det mål at få smidt bolsjevikkerne ud af landet. Vestmagterne hang nølende i hver sin ende af det store land, briterne i Nordrusland og amerikanerne/japanerne ved Stillehavet. Hjemme i København lod Harald sig indstille som præsident for The International Russian Relief Committee, finansieret af finansmanden Harald Plum, men da Udenrigsministeriet så med stor skepsis på Haralds initiativer, lod han sig tilknytte som "konsulent". Et af foreningens mål var etableringen af en hær af de omtrent to millioner russiske krigsfanger i Tyskland og Østrig-Ungarn, og få den sat ind mod bolsjevikkerne. Men planen var fuldstændig urealistisk. De russiske krigsfanger var udsultede, og ingen kunne klare mere krig efter Verdenskrigen.

\section{Danmark som neutral humanitær stat og} en oversigt over den danske hjælpeindsats Under verdenskrigen lå der et konstant pres mod de neutrale lande. Danmark frygtede Tyskland. Næsten alle neutrale lande involverede sig i humanitært arbejde, herunder i krigsfangehjælp. Allerede ved krigsudbruddet $\mathrm{i}$ august 1914 var Danmark i gang med hjælpearbejdet. Dansk Hjalpeambulance Komité organiserede ambulancer med danske læger og sygeplejersker til de allierede på Vestfronten og til Serbien. I september 1914 oprettede den danske koloni i Petersborg et lazaret $\mathrm{i}$ byen med danske læger og sygeplejersker, der skulle modtage sårede soldater. Lazarettet var under protektion af enkekejserinde Maria Fjodorovna, den 


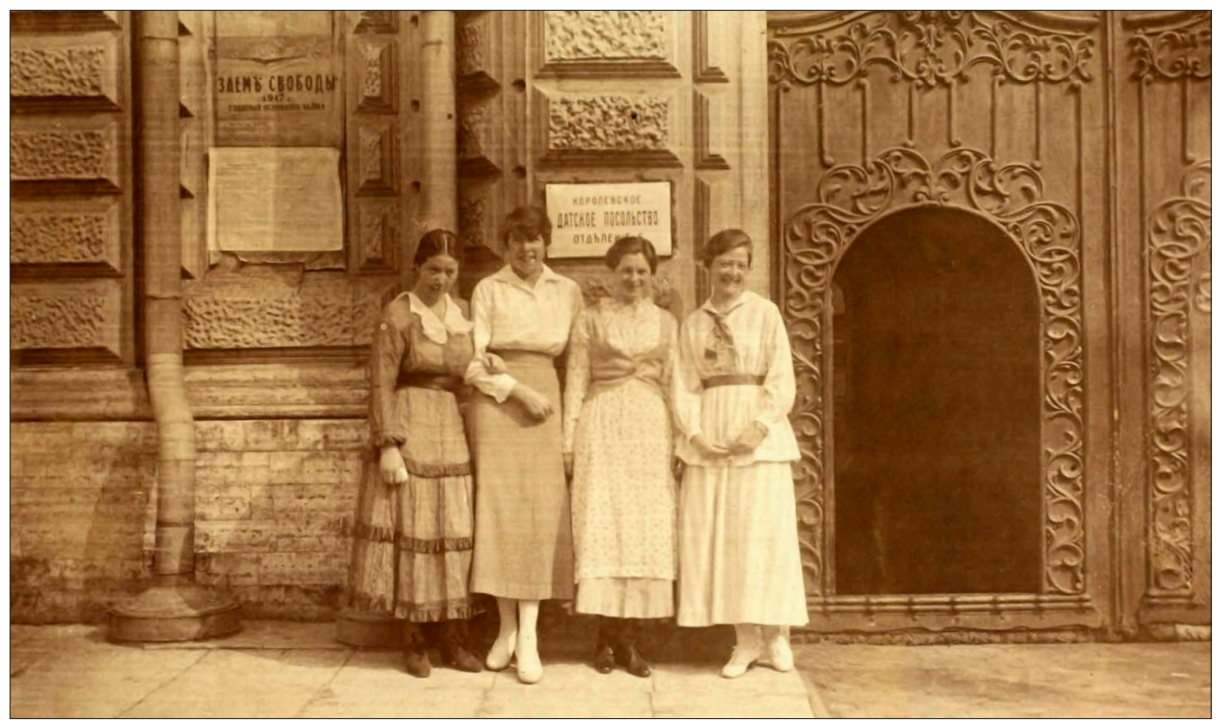

Gesandtskabets skrivedamer foran den østrig-ungarske ambassade i Petersborg, august 1917: Esther Aksel-Hansen, Ellen Haagensen, Gerda Andersen og Isabella Smith (Det Kongelige Bibliotek, Billedsamlingen).

danske prinsesse Dagmar. Året efter, i juli 1915, samlede hjælpekomiteen penge ind til en hjælpeambulance til Rusland, der skulle støtte Russisk Røde Kors, også under Dagmars protektion. Og i 1916 oprettede Dansk Røde Kors et kontor i Petersborg med oberstløjtnant Victor Philipsen som leder og senere kunstmaleren Eduard Saltoft. Siden fulgte kontorer i Moskva under ledelse af lægen Camillo Martiny 1918-19 og i Kijev.

Hjælpearbejdet var en vigtig sag for Danmark. Den internationale krigsfangehjælp var nemlig også en sag om landets suverænitet under verdenskrigen og om international politisk prestige. Harald skrev i en politisk indberetning til sin fætter, udenrigsministeren Erik Scavenius med residens på Kgs. Nytorv om "Krigsfangespørgsmålet og Dansk Røde Kors" (6. april/24. marts 1916):
"Vel er Dansk Røde Kors en privat institution, men dets virksomhed under krig er af en så stor betydning, at dets mere eller mindre heldige løsninger af de det $<$ Dansk Røde Kors> stillede opgaver vil virke tilbage på udlandets bedømmelse af hele landet. Dansk Røde Kors bliver derigennem, hvad enten man vil eller ej, udadtil en officiel repræsentant for det danske folk og dettes vilje og evne til at tage den store barmhjertighedsgerning op som ligger og venter på alle neutrale nationer. Det er ikke en ligegyldig sag, om Danmark i denne kappestrid spiller fallit".

Det dansk organiserede og ledede internationale hjælpearbejde ville således styrke den danske stat og bidrage til dens overlevelse. Derfor var hjælpearbejdet en del af dansk udenrigspolitik, og arbejdet skulle styres fra Udenrigsministeriet. 


\section{Krigsfangeinspektionerne}

Der blev også foretaget krigsfangeinspektioner. Under hele verdenskrigen rejste danske officerer og læger på Røde Kors krigsfangeinspektioner på begge sider af østfronten. I selskab med russiske, tyske og østrigske Røde Kors sygeplejersker tilså de danske officerer russiske krigsfanger i krigsfangelejre i Tyskland og Østrig-Ungarn, og tyske og østrig-ungarske krigsfanger i lejre i Rusland og Sibirien. Det var de såkaldte "søsterdelegationer". Udover det rent humanitære formål, herunder udvælgelsen af krigsfanger til lazaretophold i Danmark, i Hald og Horserød, var der også et efterretningsmæssigt. Officererne indberettede om politiske strømninger blandt krigsfangerne til Krigsministeriet i København. Såvel danske som udenlandske regeringer holdt øje med bolsjevismen i Europa og Rusland, men også i krigsfangelejrene.

Derudover var der militære efterretningsopgaver. Krigsministeriet udsendte officerer på krigsfangeinspektioner til Rusland "for på så nært hold som muligt at følge krigsoperationerne og indhente erfaringer af betydning for forsvaret". Den danske hær havde dog ingen egen interesse i militære efterretninger. Operationerne hed: "studierejser med særligt formål" og formålet var "at indhente oplysninger, der kunne interessere den danske hær "især om alt det nye, der er kommet frem eller kommer frem under den nuværende krig, såvel kampmåder som kampmidler".

Krigsministeriet tog særlig interesse i det russiske luftforsvar.

\section{April 1917}

Den 6. april 1917 gik USA ind i krigen. USA havde været beskyttelsesmagt for centralmagterne i Rusland. De måtte nu finde nye beskyttelsesmagter. Sverige overtog Tysklands interesser og Danmark overtog Østrig-Ungarns. To dage senere havde Harald Scavenius udarbejdet en organisationsplan, og i løbet af tre uger blev

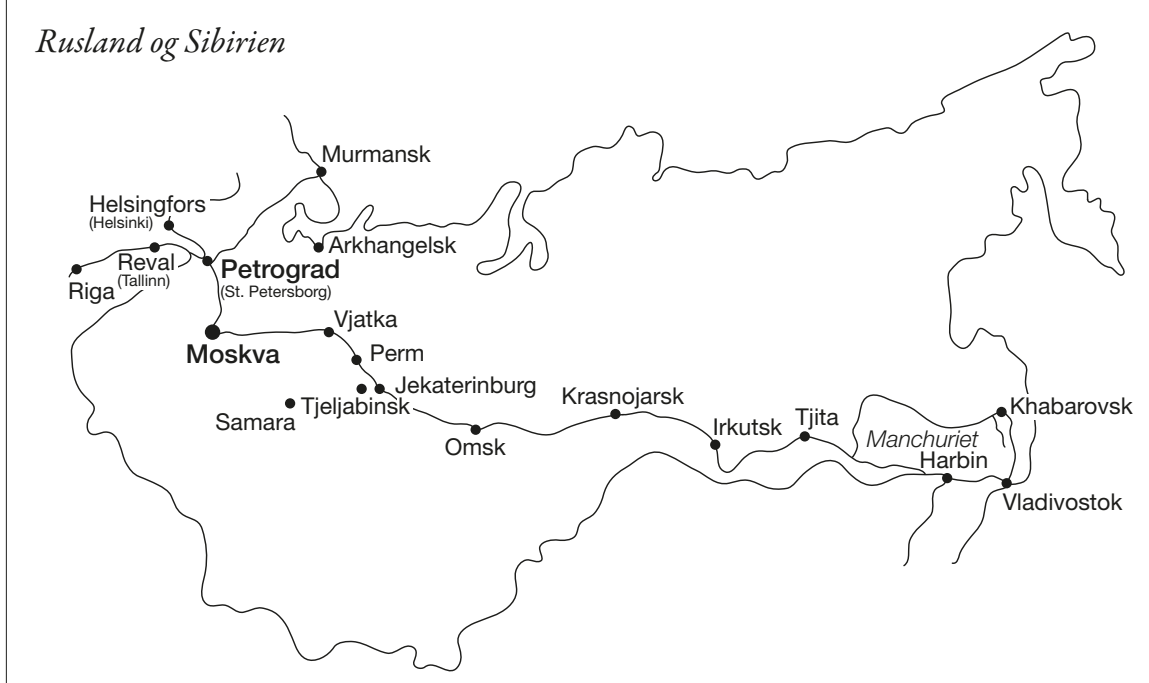


Petersborg gesandtskabet udvidet med en afdeling B for krigsfangehjælp, nemlig "afdelingen til varetagelse af østrig-ungarske interesser". Gesandten blev den øverste chef for operationen, der blev betalt af den østrig-ungarske stat.

Hjemme i København ansatte Udenrigsministeriet i huj og hast i aprils sidste dage personalet - et halvt hundrede danskere, der blev sendt af sted i maj 1917. Ansættelseskriteriet var: kendskab til russisk. De ansatte kom fra borgerskabet og mange blev siden til noget i det det danske samfund, herunder Gustav Rasmussen, Hans Hartvig Seedorff og mange flere. Gesandtskabet ansatte danske krigsfangedelegerede, der blev udstationeret i femogtyve byer i Rusland og Sibirien. De skulle besøge krigsfangelejrene, administrere pengefordelinger, undersøge sundhedstilstanden og senere organisere hjemtransporter. De delegerede sendte udførlige rapporter tilbage til gesandtskabet. Min egen interesse er netop de danske krigsfangedelegeredes oplevelser på inspektionsrejser til lejrene over det store land fra Kijev til Vladivostok, fra Ishavet til Sortehavet til Stillehavet.

\section{Rusland og krigsfangerne}

\section{- statskuppet 1917}

Tsar-Rusland havde ikke interesseret sig for krigsfangernes tarv og der var logistiske problemer med forsyninger i det store land. Efter oktoberkuppet i 1917 gik det rent galt, og gesandtskabet måtte udvide sin organisation, såvel i Petersborg som i Moskva. Revolutionen medførte opløsning i fangelejrene, officererne blev afsat og vagtmandskabet forlod deres poster. Trotskij proklamerede alle menige krigsfanger som frie mænd til gesandtskabets gru. Resultatet ville nemlig blive halvan-

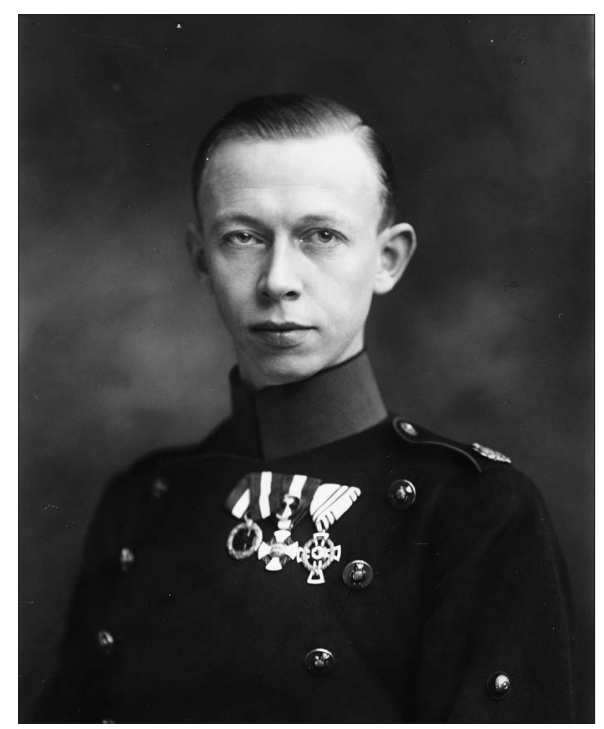

Gustav Rasmussen 1924 (Det Kongelige Bibliotek, Billedsamlingen).

den million mænd uden ernæring, klæder, hospitaler og transport. De ville søge mod byerne med sygdomsepidemier og elendighed i kølvandet. Det lykkedes gesandtskabet at overtale Trotskij til at opgive ideen i praksis, og mændene blev beordret at forblive i lejrene, indtil hjemtransporter kunne organiseres. Mange mænd blev opslugt af borgerkrigen og tvunget til at kæmpe på rød side eller hvid side.

\section{Tiggernes hær}

Selvom krigsfangerne havde fået ordre på at blive i lejrene, strømmede mange alligevel til Moskva og Petersborg. Ved årsskiftet 1917/18 kom der pludselig otte tusind af dem til Petersborg. Der blev hurtigt nødstilstand. Gesandtskabet oprettede en asylsektion, en fødevaresektion og et bageri, hvor fangerne selv bagte brød. Danske sekretærer, herunder Gustav 


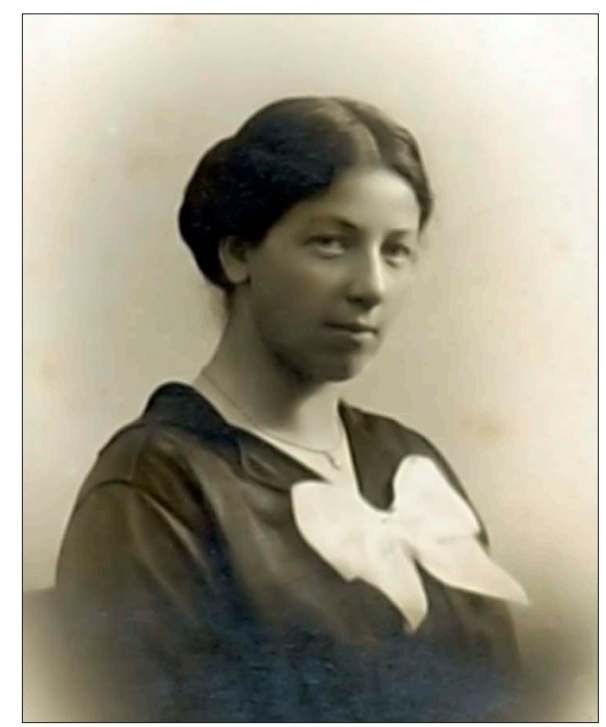

Esther Aksel-Hansen 1919 (Privateje).

Rasmussen tog sig af fordelingen af syge krigsfanger til hospitalerne, sørgede for bedre kost, og gesandtskabet overtog seks større hospitaler. Gesandtskabet organiserede togtransporter af syge og invalide fra Warszawa-banegården, og der blev oprettet fødevaredepoter og hospitaler. Med hver transport fulgte en dansk delegeret. Her skal fortælles to skæbnefortællinger, den ene om en kontordame ved gesandtskabet i Petersborg, den anden om en dansk delegeret, der kom af dage under den russiske borgerkrig.

\section{Esther Aksel-Hansen}

I april 1917 sad Esther i København, hvor hun gav privatundervisning i russisk. En elev, en sekretær i Udenrigsministeriet, fortalte om stillingsopslagene som skrivedame ved gesandtskabet i Petersborg. Esther søgte og fik jobbet. Hun havde lært sig russisk under halvandet års ophold i Rybinsk, nordøst for Moskva. Esther fik tre dage til at pakke, og søndag den sjette maj 1917 rejste hun med den danske legation til Petersborg. Esther sad nu i Harald Scavenius' forkontor. Hun renskrev rapporter og gesandtens politiske indberetninger til fætteren, udenrigsministeren $\mathrm{i}$ København; og Esther pakkede kurerposten. Fra maj 1917 til maj 1918 skrev hun ethundrede lange breve til sin mor. De kom med kurerposten til Udenrigsministeriet i København, hvor familien hentede dem. Brevene, der efterhånden fik karakter af dagbogsoptegnelser, er skrevet med journalistisk flair. De er skrevet i nuet med en krigskorrespondents øjne. Om natten skrev Esther om dagens intriger på gesandtskabet, om dagligdagens brødmangel, om truende hungersnød og om døende heste i gaderne. Stik imod gesandtskabsordre gik hun med i gadens demonstrationer. Hun kørte slædeture gennem et isnende Petersborg og besøgte byens banegårde om natten. Esthers omgang med gesandtskabets tavshedspligt er noget tvivlsom. I ny og næ hændte det, at en fortrolig gesandtskabsrapport eller en politisk indberetning fik et ekstra gennemslag, der blev sendt med nattens brev hjem til mor. Esthers breve, hvis original bevares på Det Kongelige Bibliotek, er en hovedkilde til hverdagen på Petersborg gesandtskabet i 1917 og 1918, men også en øjenvidneberetning fra oktoberkuppet i Petersborg.

\section{Frits Brøndal}

Frits Brøndal var seksogtyve år gammel og bogholder i Magasin du Nord på Kgs. Nytorv. Han kedede sig, for sidst i april 1917 krydsede han torvet og gik ind i Udenrigsministeriet. Her søgte han en stilling som delegeret ved Petersborg gesandtskabet, fik den med sit begynder- 
russiske - og ugen efter, søndag den sjette maj, rejste han med den danske legation til Petersborg. Brøndal blev sendt videre til generalkonsulatet i Moskva som sekretær for krigsfangeposten. Som mange gesandtskabsdelegerede, gik Brøndal over til Dansk Røde Kors for at fortsætte hjælpearbejdet, da gesandtskabsindsatsen var under afvikling. Han tilsluttede sig Dansk Røde Kors i Moskva i november 1918, og kom til at beskæftige sig med krigsfangetransporter fra Sibirien til Tyskland. Her skulle han tage sig af syge krigsfanger på sanitetstog. Nu holdt han regnskab - som bogholder - med invalidetransporter. Da Dansk Røde Kors oprettede et kontor i Kijev, blev Brøndal udset til leder og rejste til Kijev i januar 1919.

I 1919 lå Ukraine i borgerkrigskaos. Denikins styrker og bolsjevikkerne, altså de hvide og de røde, lå i kamp med hinanden og med ukrainske selvstændighedsstyrker. Når parterne ikke slog hinanden ihjel, myrdede de jøder. Vi husker de voldsomme jødepogromer i Ukraine i 1919, hvor den hvide hær, den røde hær, den polske hær, ukrainske selvstændighedsenheder, krigsherrer og kosakker dræbte jøder i titusindvis.

I juli 1919 ophørte Dansk Røde Kors i Rusland sin virksomhed. Dansk Røde Kors kontor i Moskva var blevet endevendt af tjekaen (det bolsjevikiske politi) og Dansk Røde Kors' medarbejdere blev fængslet i Burtika og Lubijanka. Brøndal fik ordre om at rømme kontoret i Kijev og rejse til København med arkivet. Rejsen kunne gå over Moskva, Odessa eller Østrig. Han trak på afrejsen, for han kunne ikke nå Moskva med jernbanen, der var intet skib i Odessa, og han ville ikke gå til fods til Wien, for så kunne han ikke få arkivet med. Arkivet indeholdt

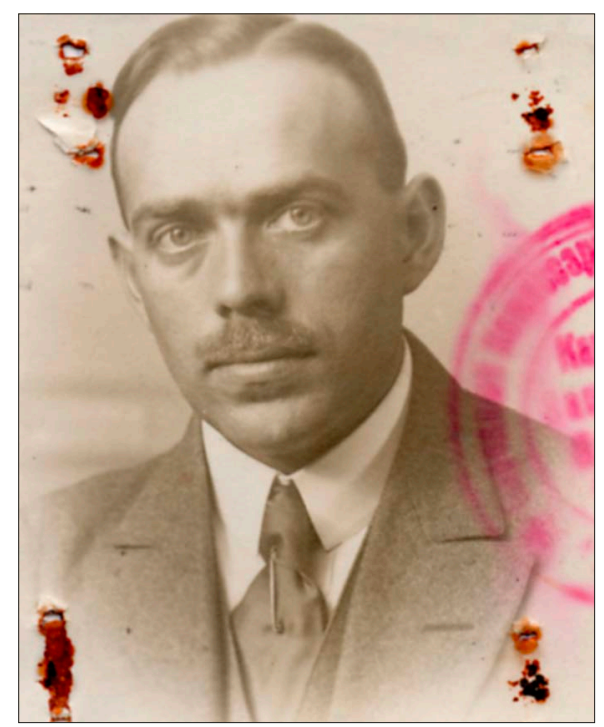

Frits Brondal 1919 (Rigsarkivet).

oplysninger om forholdene i Ukraine, om Russisk Røde Kors’ og Dansk Røde Kors' virksomhed, om Russisk Røde Kors' frontlinieinstitutioner "indkøb af fødemidler til russiske fanger i Østrig og Tyskland, og om underbringelse af de tusinder af fanger, der til fods vandrer bort fra disse lande og gennem Ukraine søger mod Rusland". Dansk Røde Kors i Kijev arbejdede med hjælpevirksomhed og fremskaffelse af levnedsmidler. Kontoret havde ansvaret for beskyttelsen af østrigungarske og tyske krigsfanger, der under usle forhold vandrede den anden vej, mod vest. Da de hvide erobrede Kijev fra bolsjevikkerne i august 1919, var Brøndal optimistisk efter at have set de rødes terror. Optimismen var dog ubegrundet. Hvide politienheder endevendte Dansk Røde Kors' Kijev-kontor. Kontoret blev på den hvide general Denikins ordre beskyldt for spionage og samarbejde med Tyskland og bolsjevikkerne. Brøndal blev 


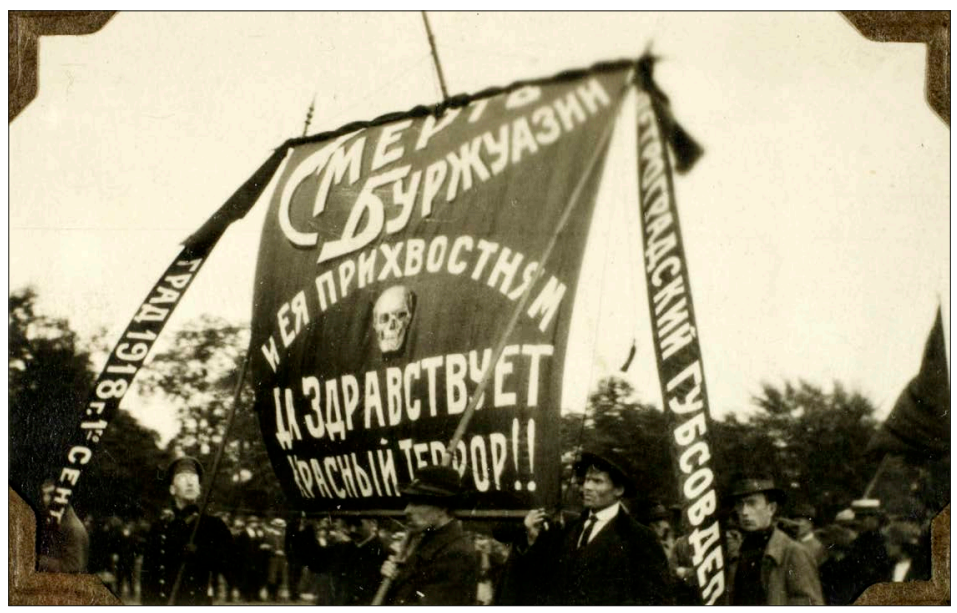

"Død over burgøjserne og dets spytslikkerlakajer. Lange leve den rode terror!! Petrograd 1918, 1. september. Petrograds guvernementssovjet af arbejder-, bonde-ogrodarmistdeputerede" (Det Kongelige Bibliotek).

anklaget som bolsjevikspion, tyskersympatisør og jødehjælper. Nu var der hvid terror i Kijev. Han havde skrevet under på ikke at forlade Kijev, men rejste alligevel til Rostov ved Don, hvorfra han ville forsøge at rejse over Krim og Sortehavet med Dansk Røde Kors' arkiv. Frits blev arresteret i Rostov ved Don. Her havnede han i et hviderussisk fængsel med en dødsdom ved skydning. Men inden de hvide fik ham skudt, flygtede den hvide hær fra Rostov ved Don, da bolsjevikkerne indtog byen. Brøndal blev glemt. Han døde af plettyfus i Rostov-fængslet i julen 1919. Brøndal var blot én af flere danske hjælpearbejdere, der gik til i den russiske borgerkrig, døde af sygdom, ved selvmord eller blev myrdet.

\section{Danaktion}

I 1920 blev alle danske civilister evakueret fra Rusland og Sibirien ved Dansk Røde Kors' hjælp, og samme år blev al officiel dansk hjælp i Rusland og Sibirien indstillet. Men de østrig-ungarske kvinder henvendte sig til kvinderne i den danske rigsdag med et opråb om krigsfangehjælp.
Resultatet blev etableringen af Danaktion: Dansk Hjalpeaktion for Krigsfangers Hjemsendelse 1920-21. Nationernes Forbund havde overdraget opgaven med at varetage hjemsendelse af krigsfanger til nordmanden Fritjof Nansen. Nansens $ø$ konomiske midler fra regeringen var tildelt til evakueringen fra den russiske grænse og hjem, men der var ingen midler til at holde liv i de syge, gamle og invalider i Sibirien. Danaktion besluttede derfor, som et selvstændigt led i Nansen-hjælpen, at sende en delegeret til den sibiriske grænse for at oprette en hjælpestation. Den skulle hjælpe hospitaler og støtte under evakueringen fra Sibirien. Bolsjevikkerne forsøgte at evakuere krigsfanger fra Sibirien, men de magtede ikke opgaven. Togene stod stille mellem forplejningsstationerne. Ved en transport blev syv tusind invalider sendt af sted mod Tyskland. Ingen nåede frem, meddeler en rejserapport. Hvorvidt alle døde, hvad givet er tænkeligt, meddeler rapporten ikke. Danskerne overtog hjælpearbejdet; de var gode til logistik, organiserede evakueringskomitéer blandt fangerne og indrettede køk- 
Sibirien 1919

(Privateje).

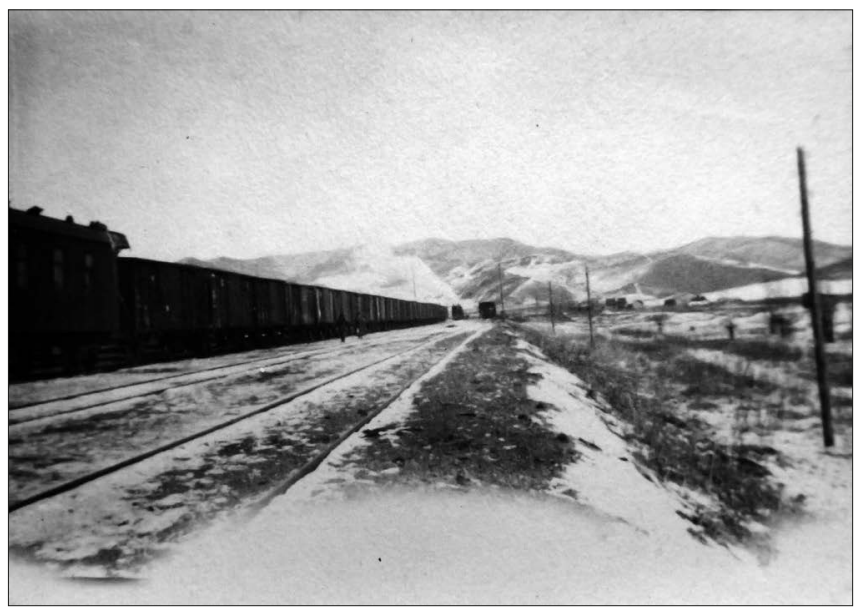

kenvogne i togene. Danaktions praktiske leder i Sibirien var statsråd Carl Andreas Koefoed. Han blev nægtet indrejsetilladelse i Sovjetrusland i december 1920. "Meddel Koefoed, at det ikke er personligt, men da den danske regering forholder sig fjendtligt overfor Sovjetrusland, nægtes danske borgere indrejsetilladelse i Rusland. Om end Koefoed ikke rejser for den danske regering, men for Nansen, må vi overholde princippet” meddelte den sovjetrussiske topdiplomat Maksim Litvinov. ${ }^{4}$ Hermed var dansk krigsfangehjælp et overstået kapitel i Sovjetrusland.

\section{Eftertanke}

Dansk udenrigspolitik under første verdenskrig er kendt for den forsigtighed, hvormed Erik Scavenius manøvrerede. Han ville opretholde dansk neutralitet og sikre, at Danmark ikke blev inddraget i krigen. Det er således overraskende, hvor markant Danmark optrådte i Rusland i krigens sidste år 1917-18. Det danske gesandtskab var i det kaotiske år 1918 den største diplomatiske repræsentation i Petersborg. Gesandtskabet bistod de østrig-ungarske krigsfanger med forsyninger og hjemtransport, og gesandtskabet bistod også mange andre, blandt andre britiske og franske statsborgere i vanskeligheder. Det var en kolossal organisatorisk opgave. Den blev løst med stor dygtighed, og den gjorde Danmark til en "humanitær stormagt" med det formål at sikre Danmarks overlevelse og dermed landets suverænitet under verdenskrigen. Østrig-Ungarn takkede den danske stat hjerteligt, og Harald Scavenius fik en medalje. Hjemme i Danmark druknede indsatsen - som i øvrigt ikke optog de danske medier - i Landsmandsbankens krak i 1922 og i de kolossale danske økonomiske tab i Rusland efter oktoberkuppet 1917. Historien blev aldrig skrevet og indsatsen blev glemt. Men i arkiverne - såvel i danske og udenlandske nationalarkiver som $\mathrm{i}$ danske privatarkiver - ligger mængder af uberørt arkivmateriale, der bare venter på at få vendt papirbunkerne. Bunkerne beretter om menneskeskæbner bag fronten - og dansk udenrigspolitik - kort sagt: Danmarkshistorie. 


\section{Noter}

1 Scavenius 1959, fortale.

2 Rigsarkivet: Udenrigsministeriet, depecher fra Moskva (lbn. 271).

3 Rigsarkivet: Moskva og St. Petersborg, dipl. repr. (2-0398), journalsager (aflev. 1940/2, pk. 6), jr. nr. 3. A. 3 (lbn. 183). Oberstløjtnant af ingeniørkorpset Jens Peter Marius Mathias Christensen.

4 Rigsarkivet: C. F. Haxthausens privatarkiv (7628).

\section{Litteratur}

Adriansen, Inge: Ivan fra Odessa: krigsfanger fra Nordslesvig og Danmark 1914-1920. 1991, s. 69.

Blüdnikow, Bent: Krigsfanger: krigsfanger $i$ Danmark under 1. Verdenskrig. 1988.

Blüdnikow, Bent: Denmark during the First World War. Journal of Contemporary History. October 1989:24, s. 683-703.

Cramer, Frits: Rapports sur les visites des camps de prisonniers en Russie et en Autriche-Hongrie par des délégations de la Croix Rouge danoise. 1916-17.

Dansk Røde Kors: Hjalp ydet fra Danmark til de krigshargede lande under og efter Verdenskrigen 1914-18. 1921.

Davis, Gerald: "National Red Cross Societies and Prisoners of War in Russia 191418", Journal of Contemporary History 1993:28/1, s. 31-52.

Erichsen, Michella: "De nordiske landes hjælp til krigsfangerne i Sibirien under og efter Verdenskrigen", Nordisk tidsskrift, 1939, s. $292-308$
Jensen, Bent: Danmark og det russiske spørgsmål 1917-24. 1979, s. 34.

Jensen, Bent: “Dansk Røde Kors' Ruslandsmission 1918-19", Historisk tidsskrift 101: 1,2001, s. 45-75.

Kjølsen, Klaus og Viggo Sjøqvist: Den danske udenrigstjeneste 1770-1970. 1970, 1, s. 364-370.

Møller-Holst, Jens: Krigsfangerne i Rusland og Sibirien 1914-20 og Danaktions hovedformål: dansk hjelpeaktion for krigsfangers bjemsendelse. 1920.

Nachtigal, Reinhard: „Die dänisch-österreichisch-ungarischen Rotkreuzdelegierten in Rußland 1915-18“, Zeitgeschichte 25:11/12, 1998, s. 366-374.

Preben-Hansen, Bernadette: „Frits Brøndal: fra Magasin du Nord til døden i et fængsel i Rostov ved Don. Dansk krigsfangehjælp i Rusland og Ukraine 1917-19", Siden Saxo 27:3, 2010, s. 26-37.

Preben-Hansen, Bernadette: "Da danskerne rejste fra borgerkrigen. Dansk krigsfangehjælp i Rusland og Sibirien 1917-20", Personalhistorisk Tidsskrift 2011:1, s. 90-116.

Preben-Hansen, Bernadette: "Dansk Røde Kors mindetegn: Dansk krigsfangehjælp 1914 til 1919", Personalhistorisk Tidsskrift 2012:1, s. 69-104.

Preben-Hansen, Bernadette: "Esther Aksel-Hansen fra Petrograd - juli til november 1917", Fra Krig og Fred: Dansk Militerhistorisk Kommissions Tidsskrift 2014:1, s. 60-85.

Scavenius, Erik. Dansk udenrigspolitik under den forste Verdenskrig. 1959. 